\title{
Use of technologies by nurses in the management of primary health care
}

\author{
Utilização de tecnologias por enfermeiros no gerenciamento \\ da Atenção Primária à Saúde
}

Uso de tecnologías por enfermeras en el manejo

de la atención primaria de salud

\author{
Bruno César Gomes Fernandes ${ }^{a}$ \\ José Nildo de Barros Silva Júniorb \\ Haline Costa dos Santos Guedes ${ }^{b}$ \\ Diego Bruno Gonçalves Macedo ${ }^{c}$ \\ Matheus Figueiredo Nogueira ${ }^{a}$ \\ Anne Jaquelyne Roque Barrêto ${ }^{b}$
}

How to cite this article: Fernandes $B C G$, Silva Júnior JNB, Guedes HCS, Macedo DBG, Nogueira MF, Barrêto AJR. Use of technologies by nurses in the management of primary health care. Rev Gaúcha Enferm. 2021;42(spe):e20200197. doi: https://doi.org/10.1590/19831447.2021 .20200197 aniversidade Federal de Campina Grande (UFCG), Unidade Acadêmica de Enfermagem. Cuité, Paraíba, Brasil.

- Universidade Federal da Paraíba (UFPB), Programa de Pós-Graduação em Enfermagem. João Pessoa, Paraíba, Brasil.

'Faculdade de Enfermagem Nova Esperança (FACENE). João Pessoa, Paraiba, Brasil.

\section{ABSTRACT}

Objective: To analyze the management actions of nurses in Primary Health Care services from the perspective of technologies. Method: Descriptive-exploratory study with a quantitative approach, carried out from February to April 2019. Through the snowball technique, the sample consisted of 42 nurses from Primary Health Care, using an electronic tool for data collection. The data were analyzed using descriptive statistics techniques.

Results: $54.8 \%$ of nurses use technologies through SISREG and PEC electronic systems, care training related to permanent health education, online and face-to-face courses, in addition to care technologies such as telehealth and telemedicine.

Conclusion: Management actions focused on technology showed restricted use. Nurses need to empower themselves with these organizational devices, with the aim of improving the provision and quality of care for users.

Keywords: Nursing. Primary health care. Health management. Biomedical technology.

\section{RESUMO}

Objetivo: Analisar as ações de gerenciamento de enfermeiros em serviços de Atenção Primária à Saúde na perspectiva das tecnologias.

Método: Estudo descritivo-exploratório com abordagem quantitativa, realizado de fevereiro a abril de 2019. Através da snowball technique, a amostra foi composta por 42 enfermeiros da Atenção Primária à Saúde, utilizando-se ferramenta eletrônica para coleta de dados. Os dados foram analisados por meio de técnicas de estatística descritiva.

Resultados:54,8\% dos enfermeiros utilizam tecnologias através de sistemas eletrônicos SISREG e PEC, da qualificação do cuidado relacionada a educação permanente em saúde, de cursos online e presenciais, além do uso de tecnologias do cuidado como 0 telessaúde e a telemedicina.

Conclusão: As ações de gerenciamento voltadas a tecnologia apresentaram utilização tímida. Nurses need to become empowered through these organizational devices in order to improve assistance and quality of care to users.

Palavras-chave: Enfermagem. Atenção primária à saúde. Gestão em saúde. Tecnologia biomédica.

\section{RESUMEN}

Objetivo: Analizar las acciones de gestión del enfermero en los servicios de Atención Primaria de Salud desde la perspectiva de las tecnologías.

Método: Estudio descriptivo-exploratorio con abordaje cuantitativo, realizado de febrero a abril de 2019. Mediante la técnica de bola de nieve, la muestra estuvo conformada por 42 enfermeros de Atención Primaria de Salud, utilizando una herramienta electrónica para la recolección de datos. Los datos se analizaron mediante técnicas de estadística descriptiva.

Resultados: El 54,8\% de los enfermeros utilizan tecnologías a través de los sistemas electrónicos SISREG y PEC, la calificación de la atención relacionada con la educación permanente en salud, cursos en línea y presenciales, además del uso de tecnologías de atención como la telesalud y la telemedicina.

Conclusión: Las acciones de gestión centradas en la tecnología mostraron un uso tímido. Las enfermeras deben empoderarse con estos dispositivos organizativos, con el fin de mejorar la atención y la calidad de la atención para el usuario. Palabras clave: Enfermería. Atención primaria de salud. Gestión en salud. Tecnología biomédica. 


\section{INTRODUCTION}

Despite advances in nursing care management, technology emerges as a tool to enhance the quality of management in primary health care (PHC). Although progress is recognized in discussions and research, nurses do not always have equitable access to these resources and services, thus weakening the health policies developed in response to $\mathrm{PHC}^{(1)}$.

$\mathrm{PHC}$ is recommended as a priority gateway for user access to the public health service and as the coordinator of care, organizer of the health care network, and responsible for the comprehensiveness and longitudinality of care. Along these lines, the use of technologies has increased in recent decades as a way of enhancing health care practices, expanding intercommunication, and producing knowledge ${ }^{(2)}$.

Technology is understood according to the collective construction, as it has several meanings, and it is represented by the "treatise on technique", "common sense and current language", "set of techniques available to a society", and as "ideology of technique". However, the study approach is based on the third sense, in which technology is related to the degree of development of nursing practices to enhance management in $\mathrm{PHC}^{(3)}$.

From the standpoint of the organizational system of PHC, technology emerges as a way of optimizing and maximizing health benefits with available resources, as well as ensuring equitable user access to safe and effective technologies ${ }^{(2,4)}$.

The work process in PHC should be organized for teams to ensure universal access and comprehensiveness of care and to improve well-being and working conditions. PHC requires professionals with vast knowledge and technical skills to promote the political and management dimensions of care-related work ${ }^{(5)}$.

$\mathrm{PHC}$ is recommended as an intersectoral organization base due to its proximity to the community; however, there are concerns about the introduction of technology in this service due to its gradual inclusion. Thus, it hinders the incorporation and fragmentation of care, which weakens the quality of care, due to the concession of parameters that support decision-making regarding current policies. $\mathrm{PHC}$ requires support and resources to break this intersectoral fragmentation and guarantee equitable user access to care $^{(6)}$.

The main actor for the implementation of these organizational devices in PHC is the nurse. With the aim of promoting nursing worldwide, the "Nursing now" campaign was developed from the initial agreement of the International Council of Nurses, World Health Organization, and the All Party Parliamentary Group on Global Health of the United Kingdom from a moment of concern and reflection that revealed the importance of nursing to fill gaps in health care, especially when considering the contribution of nurses as undervalued and limited by social values. This perspective raised the need to point out new paradigms, which are represented in the present study by technology with the purpose of expanding universal health care $^{(7)}$.

Therefore, the potential of nursing directed through the guidelines of the triple impact proposed in "Nursing now" is unquestionable when seeking to valorize the category in terms of its impact on global health care through this ambitious project, which additionally focuses on the training, valorization, and visibility of nurses and their worldwide contributions to the health of users, family, and community from the use of technology ${ }^{(7)}$.

Health-related technologies significantly enhance the work process in $\mathrm{PHC}$ by ensuring the production of information related to management, supporting the generation of new knowledge and social control, and enabling the collection of epidemiological data for effective health inspection ${ }^{(8)}$.

For this reason, management through these devices is considered the key to improving health care. Nurses are important social actors in this management process due to their extended care management work in $\mathrm{PHC}$, especially in terms of their capacity to holistically understand health care, which further emphasizes the relevance of their autonomy and decision-making and reinforces the commitment to qualify the care provided in $\mathrm{PHC}^{(9)}$.

Therefore, this study is justified by the need to expand research on how nurses working in $\mathrm{PHC}$ have been developing their activities in management, especially regarding the use of technologies that contribute significantly to the improvement of PHC services. The guiding question in this study was the following: What are the management actions performed by nurses in PHC services related to technologies?

Thus, this study aims to analyze the management actions of nurses in PHC services from the perspective of technologies.

\section{METHOD}

This is a descriptive-exploratory study with a quantitative approach conducted within PHC in Paraíba, Brazil. The state 
has 1,400 family health strategy (FHS) teams distributed in three health macro-regions across its 223 municipalities.

Data were collected from February to April 2019 and the participants were selected using the intentional non-probabilistic sampling technique from a reference chain or snowball technique ${ }^{(10)}$, contributing to the non-random recruitment of participants. This technique values the importance of knowledge and/or experience in reference to the research object in order to achieve a consensus of specialized ideas.

Thus, the following initial key informant of the study was intentionally identified and selected: a nurse who has worked in the public PHC service for more than 10 years with relevant multicenter performance and a wide network of contacts in the area, and whose attributes justify the choice. The participant was asked to list names, contact information, and email addresses of nurses with equivalent characteristics that could meet the sample selection criteria, who would, in turn, indicate others, and so on, until selection of all the individuals included in the sample.

The population considered for the study was 1,389 nurses working in PHC in the state of Paraíba. However, after possible participants were identified in the reference chain, a contact network of 153 nurses was created, of whom 42 accepted to participate in the research by submitting a positive response, thus configuring sample composition and ensuring equitable representation of all macro-regions of the state. The participants complied with the following inclusion criterion: working in $\mathrm{PHC}$ services for at least two years. Professionals who, at the time of collection, were on leave and/or vacation and were not available to participate in the study were excluded. After applying these criteria, 111 participants were eliminated, of which 89 did not answer the questionnaire in a timely manner, 15 refused to participate in the study, and 7 withdrew in the course of the research.

Research was conducted via email by sending a letter of presentation to invite the identified nurses and confirm their availability to participate in the study. The nurses who agreed received and signed an informed consent statement and, subsequently, received the questionnaire.

The form consisted of two sections. The first section was used to collect the participant's sociodemographic data and the second section contained questions on the technologies used by nurses and involved the characterization of the managerial work process and aspects related to the planning, monitoring, and evaluation of actions in PHC services, resulting in 21 variables.

To enable data collection, an online electronic tool provided by Google Docs was used due to its versatility and ease of access. The instrument is widely used to conduct online studies at no cost, which reduces research expenses, as it can be submitted by e-mail or through the direct link. Moreover, researchers can monitor the progress of responses collected automatically and enter the data in a spreadsheet, which enables the generation of statistics ${ }^{(11)}$.

The data obtained in the questionnaires were entered into a Microsoft Office Excel spreadsheet and analyzed in the Statistical Package for Social Science (SPSS) version 20.0. These data were analyzed through descriptive statistics in absolute and relative frequency measurements.

The study was approved by the Research Ethics Committee of the Federal University of Campina Grande (UFCG) under Certificate of Presentation for Ethical Appreciation (CAAE) No. 03565518.5.0000.5182. All ethical aspects governed by Resolution 466/12 of the National Health Council (CNS), which regulates the conduct of research with human beings, were observed (BRASIL, 2012).

\section{RESULTS}

The study participants consisted of 42 nurses. Of these nurses, $85.7 \%$ (36) are women; $50.0 \%$ (21) were between 31 and 40 years of age;66,7\% (28) worked in rural Paraíba; 45.2\% (19) had completed their undergraduate studies in nursing more than 10 years previously; 66.7\% (28) are employed by the state; $33.3 \%$ (14) had worked in PHC for more than 10 years, of which $26.2 \%$ (11) had worked in the same unit for 2 to 3 years; $54.8 \%$ (23) held a graduate degree in public health; $95.2 \%$ (40) worked between 31 and 40 hours a week; and 31.0\% (13) attended 3,000 to 4,000 users registered at the unit.

Table 1 shows the characterization of the performance of study participants related to the planning and evaluation of actions in PHC and reveals that team meetings were the most relevant tool and SISAB was the main source of information.

Table 2 shows the results of the technologies used by nurses in PHC to manage nursing care and reveals that $54.8 \%$ (23) stated they use health-related technologies and $45.2 \%$ (19) stated they do not use these technologies. Regarding the technologies, 19.0\% (08) use electronic systems; $16.7 \%$ (07) use care training; and 14.3\% (06) use care technologies. 
Table 1 - Characterization of the performance of health workers according to the planning and evaluation of PHC actions. Paraíba, Brazil, 2019. $(n=42)$

Variables $\quad$ n (\%)

\section{Planning of actions}

Yes

$41(97.6)$

No

\section{Characterization of planning*}

Team meetings

Analysis of the health status

Routine planning actions

$07(16.7)$

Division of tasks

Surveying of difficulties

Inter-intrasectoral organization

Specific territorial actions

Risk stratification

\section{Evaluation of actions}

Yes

No

\section{Characterization of action evaluation*}

Team meetings

Community health diagnosis

$17(40.5)$

Direct evaluation with the community

Direct evaluation with random health workers

$09(21.4)$

Other

\section{Sources of information for the planning and evaluation of actions and services*}

$\begin{array}{lr}\text { SISAB (e-SUS) } & 38(90.5) \\ \text { HIPERDIA } & 22(52.4) \\ \text { SISPRENATAL } & 17(40.5) \\ \text { Information System for Notifiable Diseases - SINAN } & 17(40.5) \\ \text { Information System for Live Births - SINASC } & 13(31.0) \\ \text { Other } & 12(28.6) \\ \text { Mortality Information System - SIM } & 11(26.2)\end{array}$

Source: Research data, 2019.

*Questions with multiple answers. 
Table 2 - Characterization of the technologies applied in PHC. Paraíba, Brazil, 2019. (n=42)
Variables
n (\%)

\section{Do not use technology}

Do not have time availability

Lack of access to technological resources

Unaware of technological resources

Weaknesses in the management process

\section{Use of electronic systems}

National Regulatory System (SISREG)

Citizen's Electronic Medical Record (PEC)

\section{Health care training}

Continuing health education

Online courses

Face-to-face courses

\section{Use of care technologies}

Telehealth

Telemedicine

\section{Use of institutionalized standards and materials}

Primary care journals and booklets; manuals and ordinances

\section{Use of care management technology}

Evaluation, planning, and organization related to the use of technologies

TOTAL $42(100)$

Source: Research data, 2019

\section{DISCUSSION}

Initially, the implementation of technologies in health care services lacks planning and evaluation that would increase the effectiveness of resources used and support the challenges of regionalization and constitution of health care networks. Moreover, the characterization of the mode of implementation and sources of information for planning and evaluation of actions and services should be considered to understand the factors that may interfere in non-adherence to these organizational devices ${ }^{(12)}$.

In this study, the interviewed nurses had a consubstantial function in the management of PHC and their actions were mostly planned and evaluated at team meetings. This result supports the findings of another study but differs when considering other variables such as analysis of health status, surveying of difficulties, and division of actions, thus revealing the need to optimize actions by 
involving the community and workers in the development of these activities ${ }^{(4)}$.

When the search for solutions to problems is collective, the ability to solve critical bottlenecks in the health service increases. As soon as the problems are shared among the team members, the work process is operationalized. Likewise, when this joint effort does not occur, it becomes more difficult to find solutions to problems ${ }^{(13)}$.

To ensure the planning and evaluation of actions and services, health workers use information sources such as the Health Information System of Primary Care (SISAB), Hypertension and Diabetes (HIPERDIA), the Prenatal Information System (SISPRENATAL), and the Information System for Notifiable Diseases (SINAN). These findings converge with the results of another national study ${ }^{(14)}$.

When asked about the use of technologies, a significant number of participants answered that they do not use technologies due to lack of availability, knowledge, inaccessibility, and weaknesses in the management process. This finding confirms the result of an exploratory and qualitative study carried out in the south of Brazil(15).

The literature shows that the difficulty of access is a factor that contributes to the non-use of technologies in health care ${ }^{(6)}$. This dilemma reveals that such limitations result in managerial weaknesses, which can negatively interfere with organization of the service and affect the dynamization of management, considering that the PHC plays the role of care coordinator and organizer of the health care networks (RAS) ${ }^{(4)}$.

The lack of knowledge associated with inefficient access to technologies can generate inequities in health, often related to the provision of care that is not based on the health needs of the population, thus increasing the urgency of technologies capable of transforming data into relevant information for the provision of equitable and comprehensive health care ${ }^{(6)}$.

In contrast, participants who use health care technologies stated that they mainly use electronic systems, such as telehealth, which helps increase the quality of care offered to users. The abovementioned platform expands the scope of care based on an interconnected network of state, regional, or inter-municipal projects and a work process shared by the municipal and state health secretariats ${ }^{(16)}$.

In addition, this technological tool provides other benefits, such as professional training, access to health services, quality improvement and resolution of health problems, and the reduction of waiting time for health services. All these benefits help improve and facilitate access to care ${ }^{(17)}$.
The present study identified the use of technologies in nursing management in PHC and revealed that a significant number of nurses use systems and electronics, such as SISREG and PEC.

SISREG is an organizational device that can be accessed by users on a scheduled basis as needed. It was created to fill gaps in the supply of health care and prevent the fragmentation of care by forming an organizational link within the network based on the establishment of workflows ${ }^{(18)}$.

Another study highlights the SISREG since management through regulation was designed to remedy weaknesses regarding user demands by means of protocols that improve service organization and enable integration, in addition to pursuing paths linked to the principles of SUS, the Brazilian unified health system, leading to the peak of quality and equanimity ${ }^{(12,18)}$.

The PEC, in turn, seeks to computerize records by means of online medical records created from the national health card. Thus, data can be shared through other information systems since this tool identifies user care and improves care management for Brazilians. Although the user is registered in the PEC system and again registered by a community health worker (CHW) through the primary care records, the system integrates this information into only one register ${ }^{(19)}$.

Health workers are encouraged to provide decisive assistance so they can ensure the well-being of users and meet their real needs. Moreover, nurses can observe and encourage other workers to face the challenges that may arise in the PHC work process. In this sense, nurses play an important role in $\mathrm{PHC}$ by acting as mediators of the work process and by setting the goals and objectives to be achieved by all staff, which improves the provision of care(6).

Regarding training, the prevailing resource among the interviewees was permanent health education to raise the awareness of PHC workers about the use of technology. Although a significant number of nurses participated in permanent health education, there is a predominance of CHWs and nursing technicians in comparison with other health workers. The participation and interaction of the multiprofessional team are needed to break intersectoral paradigms and modify praxis in favor of the permeability of technology in $\mathrm{PHC}^{(9)}$.

Permanent health education aims to better qualify workers in public health and transform and reorganize professional practices according to the weaknesses of the system. However, there are limitations to its implementation, often related to the deconstruction of standard planning, dissonances between planning, education, and health, and 
a shortage of policies that value this modality of education. Thus, the provision of permanent education in health care is conditioned to the management of human resources and its own planning ${ }^{(2)}$.

Notwithstanding the recommendation of the Brazilian Ministry of Health, the prevailing factor in comparison to other studies is the devaluation of health workers regarding permanent health education, which is related to the reduced number of workers per service and their non-release to participate in training of this nature or because their participation does not configure overtime. To further aggravate these difficulties, managers promote educational activities at inappropriate times and do not respect the workload of workers, which causes burnout and the participant's inability to assimilate the course contents ${ }^{(2,6)}$.

Regarding care technologies, the results point to the subtle use of telehealth and telemedicine in PHC, although it is perceived that both enhance service organization. Telehealth proposes to provide education via technology, counseling, diagnosis, and management in health care. Telemedicine has a more restricted objective, directed to online clinical services, which can be live or by asynchronous image transmissions for consultations with specialists ${ }^{(16)}$.

One study shows that the slow adoption of technology in PHC leads nursing facilitators to believe that health actions should not be replaced by video visits due to the complexity of some practices and some nurses still have negative attitudes toward organizational technological arrangements, which hinders implementation. In contrast, technology is viewed positively by a portion of the team for reporting work overload and fulfilling the community's demand through video visits or face-to-face visits, as needed, thus favoring the organization of care in a resolutive and equitable manner ${ }^{(20)}$.

For this reason, it was identified that the interviewed workers use technologies to base their management practice and offer comprehensive care to individual users, families, and the community. They use regulatory and institutional material, primary care journals, manuals, and ordinances, as well as electronic systems, even if minimally, which stresses the imminent need to strengthen their adherence to the use of these systems that integrate data and generate relevant information for the management of the health service ${ }^{(16,18)}$.

It is therefore understood that the care management through technologies in PHC does occur, albeit tenuously among nurses, thus weakening the logic of comprehensive and longitudinal care for users, families, and the community in the health care network. These results may be related to the absence of established policies that corroborate the enhanced implementation of technologies by nursing. From this perspective, greater focus on promoting the management of care practices is a requirement of nursing today. It is essential, therefore, that nurses become familiar with, learn about, take advantage of and use information systems and technologies to enhance the organization of the service, as well as contemplate PHC users holistically and equitably.

\section{CONCLUSION}

From the data collected in the present study, it was possible to achieve the proposed objective of analyzing the management actions of nurses in primary health care services from the perspective of technologies. Although timidly, nurses use technologies as an organizational device, with emphasis on the electronic systems SISREG and PEC, care training in the form of permanent health education, online and face-to-face courses, and care technologies such as telehealth and telemedicine.

This scenario indicates that primary care nurses should recognize the benefits of technological advances in management and empower themselves with the use of technologies in order to fill the gaps related to improvements in the quality of care and assistance to users and, consequently, achieve the goals proposed by the Nursing now campaign.

The limitation of the study is its descriptive-exploratory methodological design, which made it difficult to collect evidence of the use of technology by nurses in primary health care, delimited to the proposed descriptive scenario. However, the findings identified in this study provoke reflection on the practices of nurses regarding the use of technologies in primary health care, as well as its benefits for the management of care to users at the basic health unit. Nurses need to become empowered through these organizational devices in order to improve assistance and quality of care to users.

Thus, further research on the addressed subject through observational studies could provide valuable insight into nurses' performance in the routine use of technologies at their workplace. 


\section{REFERENCES}

1. Lima SGG, Brito C, Andrade CJC. Health technology assessment in Brazil - an international perspective. Ciênc Saúde Coletiva. 2019;24(5):1709-22. doi: https://doi.org/10.1590/1413-81232018245.17582017

2. Ferreira L, Barbosa JSDA, Esposti CDD, Cruz MM. Permanent health education in primary care: an integrative review of literature. Saúde Debate. 2019;43(120):223-39. doi: https://doi.org/10.1590/0103-1104201912017

3. Côté-Boileau É, Denis JL, Callery B, Sabean M. The unpredictable journeys of spreading, sustaining and scaling healthcare innovations: a scoping review. Health Res Policy Syst. 2019;17:84. doi: https://doi.org/10.1186/s12961-019-0482-6

4. Pinto LF, Rocha CM. Innovations in Primary Health Care: the use of communications technology and information tools to support local management. Cienc Saúde Coletiva. 2016;21(5):1433-48. doi: https://doi. org/10.1590/1413-81232015215.26662015

5. Galavote HS, Zandonade E, Garcia ACP, Freitas PSS, Seidl H, Contarato PC, et al. The nurse's work in primary health care. Esc Anna Nery. 2016 [cited 2020 Mar 23];20(1):90-8. Available from: https://www.scielo.br/pdf/ean/v20n1/ en_1414-8145-ean-20-01-0090.pdf

6. Facchini LA, Tomasi E, Diélio AS. Quality of Primary Health Care in Brazil: advances, challenges and perspectives. Saúde Debate. 2018;42:208-23. doi: https://doi.org/10.1590/0103-11042018S114

7. Fulton JS. Nursing now! A campaign for the future [editorial]. Clin Nurse Spec. 2019;33(1):5-6. doi: https://doi.org/10.1097/NUR.0000000000000421

8. Tenório M, Mello GA, Viana ALD. Policies for fostering health science, technology and innovation in Brazil and the role of clinical research. Ciênc Saúde Coletiva. 2017;22(5):1441-54. doi: https://doi. org/10.1590/1413-81232017225.33342016

9. Ferreira SRS, Périco LAD, Dias VRFG. The complexity of the work of nurses in Primary Health Care. Rev Bras Enferm. 2018;71(Supl 1):704-9. doi: https://doi. org/10.1590/0034-7167-2017-0471

10. Vinuto J. A amostragem em bola de neve na pesquisa qualitativa: um debate em aberto Temáticas. 2014 [cited 2020 Aug 17];22(44):201-18. Available from: https://econtents.bc.unicamp.br/inpec/index.php/tematicas/article/view/10977

11. Martins LMP, Silva EM, Marques D. Health information in the perspective of family health nurses. Rev Min Enferm. 2016;20:e932. doi: https://doi. org/10.5935/1415-2762.20160002
12. Silva HP, Elias FTS. Incorporação de tecnologias nos sistemas de saúde do Canadá e do Brasil: perspectivas para avanços nos processos de avaliação. Cad Saúde Pública. 2019;35 supl 2:e00071518. doi: https://doi. org/10.1590/0102-311X00071518

13. Gandarillas MÁ, Goswami N. Merging current health care trends: innovative perspective in aging care. Clin Interv Aging. 2018;13:2083-95. doi: https://doi. org/10.2147/CIA.S177286

14. Ohira RHF, Cordoni Junior L, Nunes EFPA. Perfil dos gerentes de Atenção Primária à Saúde de municípios de pequeno porte do norte do Paraná, Brasil. Ciênc Saúde Coletiva. 2014;19(2):393-400. doi: https://doi. org/10.1590/1413-81232014192.21952012

15. Reuter CLO, Santos VCF, Ramos AR. The exercise of interprofessionality and intersetoriality as an art of caring: innovations and challenges. Esc Anna Nery. 2018;22(4):e20170441. doi: https://doi. org/10.1590/2177-9465-ean-2017-0441

16. Zanotto BS, Etges APBS, Siqueira AC, Silva RS, Bastos C, Araujo AL, et al. Economic Evaluation of a Telemedicine Service to expand Primary Health Care in Rio Grande do Sul: TeleOftalmo's microcosting analysis. Ciênc Saúde Coletiva. 2020;25(4):1349-60. doi: https://doi. org/10.1590/1413-81232020254.28992019

17. Richard L, Furler J, Densley K, Haggerty J, Russell G, Levesque JF, et al. Equity of access to primary healthcare for vulnerable populations: the IMPACT international online survey of innovations. Int J Equity Health. 2016;15:64. doi: https://doi.org/10.1186/s12939-016-0351-7

18. Peiter CC, Lanzoni GMM, Oliveira WF. Healthcare regulation and equity promotion: the National Regulation System and the health access in a large municipality. Saúde Debate. 2016:40(111):63-73. doi: https://doi. org/10.1590/0103-1104201611105

19. Gomes PAR, Farah BF, Rocha RS, Friedrich DBC, Dutra HS. Electronic citizen record: na instrument for nursing care. J Res Care Fudam Online. 2019;11(5):1226-35. doi: https://doi.org/10.9789/2175-5361.2019. v11i5.1226-1235

20. Kozikowski A, Shotwell J, Wool E, Slaboda JC, Abrashkin KA, Karin Rhodes $K$, et al. Care team perspectives and acceptance of telehealth in scaling a home-based primary care program: qualitative study. JMIR Aging. 2019;2(1):e12415. doi: https://doi.org/10.2196/12415 


\section{- Authorship contribution:}

Conceptualization. Data curation. Formal analysis. Research. Methodology. Writing - original draft. Bruno César Gomes Fernandes.

Conceptualization. Data curation. Formal analysis. Methodology. Writing - original draft. Writing - review and editing. José Nildo de Barros Silva Júnior.

Conceptualization. Data curation. Formal analysis. Methodology. Writing - original draft. Writing - review and editing. Haline Costa dos Santos Guedes.

Data curation. Formal analysis. Writing - review and editing. Diego Bruno Gonçalves Macedo.

Conceptualization. Data curation. Formal analysis. Methodology. Validation. Preview. Writing - review and editing. Matheus Figueiredo Nogueira.

Conceptualization. Data curation. Formal analysis. Research. Methodology. Validation. Preview. Writing - original draft. Writing - review and editing. Anne Jaquelyne Roque Barrêto.

\section{- Corresponding author:}

José Nildo de Barros Silva Júnior

Email: nildoenfer@hotmail.com

\section{Associate editor:}

Dagmar Elaine Kaiser 